\title{
The Effect of Value Clarification Technique Learning Models and Learning Styles on the Achievement Learning Outcomes of Class VIII MTs Al-Hasanah Tanjung Leidong, Labura District
}

\author{
Siti Halimah ${ }^{1}$, Zulfahmi Lubis $^{2}$, Saidatun Nisa Nasution ${ }^{3}$ \\ ${ }_{1,2}$ Faculty of Tarbiyah and Teacher Training, Universitas Islam Negeri Sumatera Utara, Indonesia \\ ${ }^{3}$ Postgraduate Program in Faculty of Tarbiyah and Teacher Training, Universitas Islam Negeri Sumatera \\ Utara, Indonesia \\ saydanasty08@gmail.com
}

\section{Abstract}

The purpose of this study was to determine: (1) the influence of the value clarification technique (VCT) learning model on student learning result. (2) Knowing the influence of learning styles on student learning result. (3) Knowing the interaction between learning models and learning styles on student learning result. The population of this study were students of class VIII MTs Al-Hasanah Tanjung Leidong Labuhan Batu Utara consisting of three classes. The sample chosen for the class with the VCT learning model was class VIII-3 with 30 students, while students who were taught using the expository model were 32 students. The cluster random sampling technique is influenced by analysis of variance at a significant level $(\alpha=0.05)$ followed by Scheffe. The results of this study are: (1) the average value of students taught with the VCT learning model (=33.6) is higher than students taught with the expository learning model $(=24.68)$ with Fcount $0.0023<$ Ftable 3,988. (2) The average value of learning outcomes Akidah Akhlak with visual learning styles $(=27.5)$, auditory $(=29.56)$ and kinesthetic $(=$ 28.26) with Fcount $=0.068<$ Ftable $=3,988$. (3) There is an interaction between learning models and learning styles on students learning outcomes Akidah Akhlak with Fcount $28.96<$ Ftable 3,988. Based on the data analysis, it can be concluded that students with visual and auditory characteristics, the appropriate learning model is the VCT, while students with the kinesthetic learning style are expository. The implication is that teachers must be trained in how to understand student learning styles. Thus it is suggested that in planning the learning process the characteristics of students must be considered.
Keywords

value clarification technique; learning style

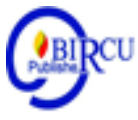

\section{Introduction}

The success of learning is largely determined by the teacher who transfers knowledge through the learning process. Therefore, teachers must be able to teach Akidah Akhlak according to the learning model used so that students do not feel bored or bored in participating in the teaching and learning process in class. Because in general, Akidah Akhlak lessons are conveyed using a conventional model (lecture).

One solution in increasing student interest and learning outcomes is the VCT learning model. This model is a learning model that helps students look for or find a value that is considered good to solve problems. In this case, students are required to think and process 
information properly and in the way they like best. Therefore, students' learning styles must also be considered in order to make it easier to absorb the knowledge that has been conveyed.

\section{Review of Literatures}

The VCT model is a series of activities that emphasize how a person actually builds values that he thinks are good and VCT emphasizes helping students assess their own feelings and actions. In this case Djajari (2012: 67) explains VCT, which is to train and foster students on how to assess, make decisions about something.

Taniredja (2011: 88) explains that VCT is a learning technique to help students achieve and determine a value that is considered good in dealing with a problem through the process of analyzing the values that already exist and are embedded in students.

Siswandi, (2009: 77) suggests that VCT is a way to instill and explore certain values from students. Therefore, in the process it functions as follows: (1) measuring or knowing the level of students' awareness of a value, (2) fostering student awareness of the values they have, both positive and negative, and then fostered towards improvement and correction, and (3) ) instill a value in students in a rational way and are accepted by students as their personal property.

Siswandi (2009: 67) explains the objectives of implementing the VCT model from a student perspective, namely: (1) helping students to realize and identify their own values and those of others, (2) helping students to be able to communicate openly and honestly towards others related to their own values, (3) helping students so that they are able to use together rational thinking skills and emotional awareness to understand their own feelings, values and behavior patterns, and (4) in implementing learning, The most important thing in implementing the VCT model in order to be effective is that there is a need for students who are willing and able to be actively involved in learning. Therefore, it is demanded that students have the potential to think critically. In this case, the role of the teacher as a motivator for learning is very important, a warm family atmosphere is also very important, so that students are not ashamed to take an active part in learning.

The objectives of implementing the VCT learning model described by Adisusilo (2014: 142) are: (1) helping students to realize and identify their own values and the values of others, (2) helping students to be able to communicate openly and honestly with others, related to the values they believe in, and (3) helping students to be able to use their intellect and emotional awareness to understand their own feelings, values and behavior patterns.

Sanjaya (2010: 285) describes the purpose of using VCT as follows. (1) knowing and measuring the level of students' awareness of a value, so that it can be used as a basis for determining the target value to be achieved, (2) instilling student awareness of the values possessed by both positive and negative levels and traits to be implanted into direction of improvement and achievement of target values, and (3) instilling certain values to students in a rational (logical) way and accepted by students, so that in the end these values will belong to students as a process of moral awareness not a moral obligation, (d) train students in receiving assess their own value and the position of others, accept and make decisions on issues related to their interactions and everyday life.

The steps for VCT learning were described by Taniredja, (2011) as follows:

\section{Freedom of Choice}

At this level, there are three stages of activities that must be carried out, namely: (a) choosing freely, meaning the opportunity to make choices which he thinks are good. The enforced value will not belong fully to him, (b) $\mathrm{m}$ Choosing from several alternatives. This means to 
determine the choice of several alternative options freely, and (c) to choose from several alternatives to consider the consequences that will arise as a result of the choice.

2. Appreciate

The level of VCT learning in this activity consists of two stages, namely: (a) the feeling of being happy and proud of the values that are chosen, so that these values will become a part of itself, (b) emphasizing the values that have become an integral part of themselves in public . This means that if we consider that value to be an option, then we will be bold enough to show it in front of others.

3. Do

The final stage in the VCT learning model consists of two stages, namely: (a) willingness and ability to try to implement it, (b) repeating the behavior according to the value of the choice. That is, the value that becomes the choice must reflect in everyday life.

Learning styles are the way we prefer to think, process and understand information (Gunawan, 2006: 139). Furthermore, the learning style according to Nasution (2006: 94) is a consistent method used by a student in capturing stimuli or information, how to remember, think and solve problems.

Therefore every student has a difference in responding to learning, some are quick to understand some are quite slow, therefore a way is needed that the teacher can do so that students continue to spur themselves to respond to learning well, here the task of the teacher must understand what style is preferred. his student.

De Porter and Hernacki (2003: 110) explain that learning style is a combination of how it absorbs, then organizes and manages information.Furthermore, De Porter and Hernacki (2003: 110) describe two main categories of learning styles, namely: (1) how to absorb information easily (modality), and (2) how to organize and process that information (brain domination). Furthermore, it is explained that learning styles are a combination of how individuals absorb, and then organize and process information.

Kolb as quoted by Mujis and Reynolds (2008: 304) explains that learning styles can be ranked along a continuum starting from: (1) concrete experiences (which are involved in a new experience through reflective observation), (2) reflective observation (observing others or developing observations). about own experiences), (3) abstract conceptualization (creating theories to explain observations), to carry out active experimentation, (4) active experimentation (using various theories to solve problems and make decisions).

Furthermore, the learning style according to Nasution (2006: 94) is a consistent way that is used by a student in capturing stimuli or information, how to remember, think and solve problems.

DePorter and Hernacki (2003: 112) explain three learning styles, namely: (1) visual, (2) auditory, and (3) kinesthetic. Visual students have pictures in their notes. In mathematics and science, tables and graphs deepen understanding. Mind maps can be excellent tools for visual learning in any subject. Visual students learn best when they start with the overall picture. Auditorial students learn by listening to lectures, examples and stories and repeating information. They prefer to record on tape rather than take notes, because they like to listen to repeated information. Kinesthetic students enjoy learning with movement and are best at memorizing information by socializing the movement with every fact, therefore learning through role playing, working on projects is very helpful. Many kinesthetic students move away from the bench, they prefer to sit on the floor and spread the work around them. 


\section{Research Method}

The research used a quasi experimental method with a $2 \times 3$ factorial design. Furthermore, the determination of the experimental class and the control class used the cluster random sampling technique. The research instruments were tests and questionnaires. The data analysis technique used was two-way analysis of variance at $\alpha 0.05$.

\section{Discussion}

The findings of the research show: (1) the learning outcomes taught by the VCT model are known to have the highest score $=40$; and the lowest score $=29$, mean $=33.6$; mode $=$ 34.1 ; median $=33,7$; variance $=5.49 ;$ standard deviation $=2.34,(2)$ the learning outcomes taught by the expository model are known to be the highest score $=35$ and the lowest score $=$ 20 mean $=24.68 ;$ mode $=22.75 ;$ median $=23.75 ;$ variance $=16.22 ;$ standard deviation $=$ 4.03, (3) student learning outcomes with the overall visual learning style have the highest score $=39$ and the lowest score $=20$, mean $=27.5$ mode $=22.5$; median $=26.78$; variance $=$ 18.9; standard deviation $=4.34$. $=$, (4) student learning outcomes with the overall auditory learning style have the highest score $=38$ and the lowest score $=21$, mean $=29.56$ mode $=$ 33.78; median $=33$; variant $=54.2$ standard deviation $=7.36$, (5) student learning outcomes with the overall kinesthetic learning style have the highest score $=36$ and the lowest score $=$ 20 , mean $=28.26$ mode $=33.3 ;$ median $=33.7$ variance $=37.5$ standard deviation $=6.12,(6)$ the learning outcomes of students who are taught using the VCT approach and visual learning styles, it is known that the highest score $=39$ and the lowest score $=30$ then the mean price is obtained $=56.66 ;$ mode $=32.16 ;$ median $=33$ variant $=1784 ;$ standard deviation $=42.23,(7)$ the learning outcomes of students taught by VCT and auditory learning styles are known to have the highest score $=38$ and the lowest score $=31$, mean $=32.5$; mode $=$ median $=33.83$; variance $=1784$; standard deviation $=42.23$, (8) student learning outcomes taught by expository learning and kinesthetic learning styles the highest score $=36$ and the lowest score 30 , mean $=33.5$ mode $=35.16$; median $=35$; variance $=18037.5$ standard deviation $=134$, (9) student learning outcomes taught by expository learning and visual learning styles the highest score was 31 and the lowest score was 20 , mean $=24.5$; mode $=24.5$; median $=24.7$; variant $=1086$ and standard deviation $=33$, (10) student learning outcomes taught by expository learning and auditory learning styles, the highest score was 35 and the lowest score was 21 , then the mean value was 24.13 ; mode $=14.1$; median $=24.1$ variant $=14.25$ and standard deviation $=3.77$, and (11) student learning outcomes taught by expository learning and kinesthetic learning styles the highest score is 32 and the lowest score is 30 , mean $=25.01$ mode $=22,5$ median $=23$ variance 18.28 and standard deviation 4.3.

Furthermore, related to the findings of hypothesis testing: (1) testing the first hypothesis, there is a difference in the learning outcomes of students' aqidah learning that is taught using the VCT learning model higher using the expository learning model, (2) testing the second hypothesis, namely that there are differences in learning outcomes of aqidah morals between students who have visual auditory and kinesthetic learning styles are verified, and (3) testing the third hypothesis, namely that there is an interaction of the influence of the VCT learning model and learning styles on learning outcomes that are verified

There are differences in the effect of the VCT learning model and the expository learning model. The first hypothesis states that the learning outcomes of students who are taught with the VCT learning model are higher than the learning outcomes of students taught with the expository learning model. 
This is understandable because through the VCT learning model it can encourage someone to actively learn because students can instill the values obtained into everyday life, and can foster active student participation in solving problems and foster discussion among students in finding causes and solutions to This issue or problem is the role of the teacher in the application of the VCT learning model as a facilitator that directs students to discover and construct their own knowledge.

This finding is also in line with Febriansyah's research which shows the average score of the application of the lecture or question and answer model is 24.5 and with VCT 89.5. It is also shown from the results of the independent $t$ test that the $t$ value is 26.32 and the data obtained is based on the t-table distribution of 2.54. The conclusion from the results of this study is that applying VCT in Civics learning has a significant effect on student Civics learning outcomes.

The second hypothesis testing shows that the learning outcomes of students with a tendency of auditory visual and kinesthetic learning styles have significant differences in learning outcomes. Kinesthetic learning styles are better than student learning outcomes with auditory and auditorial learning styles.

This indicates that students with kinesthetic learning styles on average have better learning outcomes of aqidah morals compared to students with auditory and visual learning styles, this is confirmed by Bobby De Potter (2003) saying that students who have this learning style prefer to involve movement. Usually people with this type find it easier to learn something not only by reading books but also practicing it. By doing or touching the object that is being studied, it will give a special experience for the kinesthetic type.

These findings support previous research conducted by Bire and Bire (2014) showing the relative contribution of visual auditory and kinesthetic learning styles to student learning achievement by $3,4.8 \%$, respectively, the relative contribution of each to learning achievement, namely visual learning styles $26.4 \%$. Auditory learning styles $24.2 \%$ and kinesthetic learning styles $26.2 \%$ then the results of research from Maulana's tailoring sister entitled the influence of contextual approaches assisted by unique boy media on students' mathematical understanding and connection abilities showing the application of auditory visual learning and kinesthetic can improve student learning outcomes on simple plane material elementary school students where the accumulation of student activity from the three aspects that reach the very good category in cycle $116 \%$, cycle $256 \%$ cycle $392 \%$ as well as student learning outcomes in cycle $124 \%$ cycle $260 \%$ and cycle 3 reach $88 \%$ results of Haris (2013) shows that learning styles have a relationship with learning achievement, learning styles have a significant effect on learning achievement, learning styles have a contribution or effect of $52 \%$ on learning achievement students and the remaining $48 \%$ is influenced by other variables.

Testing the third hypothesis there is an interaction between learning approaches and learning styles in influencing students' learning outcomes of aqidah morals. If it is seen that the average learning outcomes in groups of students with auditory and kinesthetic styles are better taught using the VCT learning model with the expository learning model then the average learning outcomes of morals in groups of students with kinesthetic learning styles are better taught using expository learning models compared to VCT learning model thus it can be concluded that the learning approach and learning styles significantly influence student learning outcomes. 


\section{Conclusion}

The conclusions that can be drawn from the results of the research findings are: (1) there is an influence on students' learning of Akidah Akhlak taught using the VCT model and the expository learning model. In this case the learning outcomes of the Akidah Akhlak students taught by the VCT model $(\bar{X}=33.6)$ were higher than those taught by the expository learning model $(\bar{X}=24.68)$, (2) there was a significant influence between learning styles on student learning outcomes with the comparisons are as follows; visual learning styles $\quad(\bar{X}=27.5)$, auditory $(\bar{X}=29.56)$ and kinesthetic $(\bar{X}=28.26)$, both those taught by the VCT model and the expository model, (3) there is an interaction between learning models and learning styles that give different influences towards learning outcomes of Akidah Akhlak. This is evidenced by the price of the difference in these effects: (a) the learning outcomes of students taught with the VCT model and visual learning styles $(\bar{X}=$ 56.66) are higher than those taught with expository and visual learning styles $(\bar{X}=48.57)$, (b) the learning outcomes of the Akidah Akhlak students taught by the VCT model and the auditory learning style $(\bar{X}=56.66)$ were higher than those taught with expository and auditory learning styles $(\bar{X}=24.13)$, and (c) the learning outcomes of Akidah The morals of students taught with the VCT model and kinesthetic learning styles $(\bar{X}=27)$ were higher than those taught with expository and kinesthetic learning styles $(\bar{X}=25.01)$.

The suggestions that can be given are; (1) To the Head of Madrasah as the person in charge of the management of education and learning, it is best to prioritize the program to increase the human resources of the teaching staff and the provision of learning resources/media, (2) to teachers who teach Akidah Akhlak subjects to maximize learning activities with various varied learning approaches, one of them is with the VCT model, and (3) to other researchers who want to investigate further about this learning model, they should expand the number of samples and add controlled variables so that knowledge about learning models and student characteristics is growing.

\section{References}

Amelia, L., Hayati, F., Miffayetti, S., and Ichsan. 2019. Analysis of the Use of Kindergarten Watching Siaga Bencana Learning Model for Structured Positive Thinking Ability on Early Childhood. Budapest International Research and Critics Institute-Journal (BIRCIJournal) (2): 379-387.

Ananda, Rusydi. Perencanaan Pembelajaran. Medan: LPPPI, 2019.

Bire, Arylien Ludji., Geradus, Uda dan Bire, Josua. Pengaruh Gaya Belajar Visual, Auditorial Dan Kinestetik Terhadap Prestasi Belajar Siswa. Jurnal: Kependidikan Volume 44, Nomor 2, November 2014,

De Porter, Bobbi dan Hernacki, Mike. Quantum Learning. Membiasakan belajar nyaman dan menyenangkan. Penerjemah. Alwiyah Abdurrahman. Bandung: Kaifa, 2003

Djajari. Model Pembelajaran Inovatif dan Proses Pembelajaran Konvensional. Jakarta: Balai Pustaka, 2012.

Gunawan, Adi W. Genius Learning Strategy. Jakarta: Grasindo, 2006.

Haris, Fairizah. Penerapan Model Pembelajaran VCT Untuk Meningkatkan Kesadaran Nilai Menghargai Jasa Pahlawan Pada Siswa Sekolah. Jurnal: JPGSD Volume 01 Nomor 02 Tahun 2013 
Muijs, D. dan Reynolds, D. Effective Teaching, Evidence and Practice. Alih Bahasa: Helly Prajitno Soetjipto dan Sri Mulyanti Soetjipto. Effective Teaching, Teori dan Aplikasi. Yogyakarta: Pustaka Pelajar, 2008.

Ramlan, Farizawati, and Hasrul, S. 2020. The Effectiveness of Implementation of the MGMP Revitalization Program as a Media Increasing English Teacher Competency in Pidie District. Budapest International Research and Critics Institute-Journal (BIRCI-Journal) (3): 95-103.

Rezeki, R., Sitompul, H., and Situmorang, J. 2020. The Effect of Learning Strategies and Cognitive Styles on Learning Outcomes of Mathematics after Controlling Intelligence. Budapest International Research and Critics in Linguistics and Education (BirLE) Journal (3): 1151-1163.

Sanjaya, Wina. Kurikulum dan Pembelajaran. Jakarta: Kencana Perdana Media Group, 2010.

Suryono, Mahardika, I. M. S., and Tuasikal, A. R. 2020. Pride Learning Model in Order to Improve the Physical Fitness of Indonesian Naval Academy Cadets. Budapest International Research and Critics in Linguistics and Education (BirLE) Journal (3): 235-243.

Sutarjo, Adisusilo. Pembelajaran Nilai- Karakter (Konstruktivisme dan VCT sebagai Inovasi Pendekatan Pembelajaran Efektif). Jakarta: Rajawali Pers, 2014.

Taniredja, Tukiran, dkk. Model-Model Pembelajaran Inovatif. Bandung: Alfabeta,. 2011. 